\title{
$-8-$ \\ Those Who Don't Know Speak \\ Translations of Laozi by People Who Do Not Know Chinese
}

Nowhere are the vices of thin description more apparent than in American expropriations of Daoism. It has often been said that Laozi (or Daode jing) is the most frequently translated work next to the Bible. ${ }^{1}$ But that exception may no longer hold: a typical bookstore in the United States today will have several different versions of the Daode jing on its shelves, and Americans purchase more copies of that Chinese classic than of Goethe, Molière, and possibly Aristotle. ${ }^{2}$ This trend is not surprising: the recent proliferation of Daode jing translations is simply a consequence of the increasing general interest in Asian thought. What is disturbing, however, is that alongside the many competent works, marketed at reasonable prices by a large assortment of publishers, there are now several offerings by people who declare without embarrassment that they have no knowledge of the Chinese language, let alone the ancient idiom of the Daode jing. ${ }^{3}$

It is hard to imagine how anyone can get the idea that it is possible to translate a Chinese text without knowing Chinese. ${ }^{4}$ The requisite hubris is astounding. Chinese people do not attempt to translate Shakespeare without knowing English. In certain cases, such as when a rare text has been translated only into some other language, it may be defensible, as a stopgap, to publish an indirect English translation that relies on another translation, rather than on the original text. (For instance, the Ming novel Rou putuan 肉蒲團 was unavailable in English for many years, so Grove Press published an English translation of the German translation by Franz Kuhn.) ${ }^{5}$ But those are special circumstances that do not apply to the Daode jing. There are plenty of serviceable English translations as it is. 
The standard modus operandi of these pseudotranslators is to imbibe a broad selection of scholarly translations, digest their import, and expectorate a new rendition of their own. This is an objectionable procedure: rummaging through the corpus of received translations merely circumscribes oneself within the range of interpretations that they offer and can result only in the repackaging of the same old ideas in a novel and usually gimcrack integument. ${ }^{6}$

To illustrate the problems, four such renditions are considered below: The Way of Life According to Lao Tzu, by Witter Bynner (1881-1968); ${ }^{7}$ Tao Te Ching: A New English Version, by Stephen Mitchell; Tao Te Ching: About the Way of Nature and Its Powers, by Thomas H. Miles; and Lao Tzu Tao Te Ching: A Book about the Way and the Power of the Way, by Ursula $\mathrm{K}$ Le Guin (daughter of the anthropologist A. L. Kroeber). ${ }^{8}$ All four writers freely admit that they do not command Chinese. Only Le Guin was aided by a genuine authority (J. P. Seaton, a specialist in Chinese literature at the University of North Carolina), and her book, as might be expected, is by far the best of the lot, although it too has major weaknesses. Bynner had consulted earlier with a redoubtable Chinese scholar named Kiang Kang-hu 江穴虎 (1883-1954?), ${ }^{9}$ but The Way of Life According to Lao Tzu was entirely his own work. Miles asked some unnamed Chinese students at West Virginia University to walk him through the text character by character.

Before considering these books in detail, it is worth observing that the authors justify their publications with apologies that are revealing in themselves. ${ }^{10}$ Mitchell, for example, announces that "the most essential preparation for my work was a fourteen-year-long course of Zen training, which brought me face to face with Lao-tzu and his true disciples and heirs, the early Chinese Zen Masters."11 This devotion may be admirable, but a course of Zen training, however rigorous, does not in itself qualify one to translate the Daode jing. ${ }^{12}$ The Daode jing is not a Buddhist text. In any case, it is only in an unclarified metaphorical sense that Mitchell's Zen experience could have brought him "face to face with Lao-tzu and his true disciples and heirs." Who are the "false" heirs? Who, for that matter, is Lao-tzu? (Mitchell seems to believe that there was a man named Lao-tzu who lived long ago and wrote a great book.) Far from allaying concerns, the exposition of his credentials only raises further questions about his peculiar conception of the text's history. ${ }^{13}$

Bynner, for his part, writes: "Though I cannot read Chinese, two years spent in China and eleven years of work with Dr. Kiang in translating The Jade Mountain have given me a fair sense of the 'spirit of the 
Chinese people' and an assiduity in finding English equivalents for idiom which literal translation fails to convey." 14 It is striking that Bynner felt obliged to put the phrase "spirit of the Chinese people" in quotation marks; his own conscience seems to have balked at such a self-serving platitude. To suggest, moreover, that two years spent in China in the twentieth century should provide an adequate understanding of the Chinese world over two thousand years earlier belittles one of the most vibrant civilizations on the planet. No one would propose in earnest that a sojourn in Italy would constitute sufficient training for an American to discourse on Ovid and Livy. If Mitchell's and Bynner's claims seem less than outrageous, it is only because they manipulate Americans' general unfamiliarity with the cultures of East Asia.

To Miles belongs the most ludicrous pronouncement of all. In his acknowledgments, he thanks "several Chinese students, whom I cannot name because reprisals might be taken against their families on the mainland if their work with me became known. Communist Chinese bureaucrats have, at least since the days of the Red Guards, forbidden the Chinese people to possess or read the Confucian and Taoist classics, as well as most ancient Chinese literature."15

This he writes in 1992, long after "the days of the Red Guards," at a time when state-sponsored presses in the People's Republic of China have published thousands of books and articles on "ancient Chinese literature," including every Confucian and Daoist classic, and representing an array of diverse approaches. A writer who contends that helping a foreigner read the Daode jing would make Chinese citizens vulnerable to reprisals is either uninformed or disingenuous.

To proceed now to the first of the faults shared by all of these pseudotranslations: they cull from earlier publications, but in a desultory manner; usually, they take someone else's idea and make it worse. ${ }^{16}$

For example, the end of chapter 2 of the received text reads:

是以聖人處無為之事, 行不言之教・萬物作而不邹, 生而不有, 為而不恃, 成功而弗居, 夫唯弗居, 是以不去。17

This is rendered by Miles as follows:

Therefore wherever the sage is, he dwells among affairs by not-doing.

He teaches without words.

The ten-thousand things arise, but he doesn't impel them. 
He gives birth, but he doesn't possess.

He acts, but he doesn't rely on what he has done.

He has successes, but he doesn't claim credit.

So, by not claiming credit, he is never left empty. ${ }^{18}$

The interesting phrase here is "to claim credit," which Miles uses for $j u$ 居. The nornal sense of $j u$ is simply "to dwell, to reside," which works well in several of the most recent translations. Consider that of Victor $\mathrm{H}$. Mair: "He completes his work but does not dwell on it. Now, simply because he does not dwell on them, his accomplishments never leave him."19 Or Robert G. Henricks: "He accomplishes his tasks, but he doesn't dwell on them; it is only because he doesn't dwell on them that they therefore do not leave him." 20 Taking $j u$ in this sense also explains a textual variant that has the synonym $c h u$ 處 (to reside in, to be located in) for $j u .^{21}$

How, then, does Miles arrive at "claim credit"? The extended meanings of $j u$ include "to occupy" and hence possibly "to claim," as in "to claim territory." The phrase "claim credit" must go back to the famous translation by Wing-tsit Chan: "He accomplishes his task but does not claim credit for it. It is precisely because he does not claim credit that his accomplishment remains with him." 22 (Chan did not comment further on this idiosyncratic translation.) Miles could not have known to render $j u$ in this manner without consulting Chan. Unequipped to resolve the philological issues, Miles simply browsed through the available translations and selected the rendering of this phrase that appealed to him most.

The same clause (with chu instead of $j u$ ) appears at the end of chapter 77, and Mitchell, who avoids the idea of "claiming credit" in chapter 2, freely appropriates it here: "[she] succeeds without taking credit."23 Miles renders chu in chapter 77 dubiously as "to take advantage," 24 not observing the parallel with chapter 2. It is evident that both Miles and Mitchell have read Wing-tsit Chan and help themselves to his phrasing as it suits them. ${ }^{25}$ But neither one acknowledges his debt or reflects on the larger hermeneutic consequences of following an authority in one chapter and not in another.

Le Guin also sifts through earlier translations for help, but she uses them with more care and integrity. In her notes, she explains chapter by chapter her grounds for following various interpretations. Moreover, she usually tries to rework each passage in her own words, rather than simply copying convenient phrases from those who have preceded her. Still, 
there are times when she falls short of her own sources. In her note to chapter 69, for example, she says: "Waley is my guide to the interpretation of the second verse, but I make very free with the last two lines of it." ${ }^{26}$ The passage in question reads:

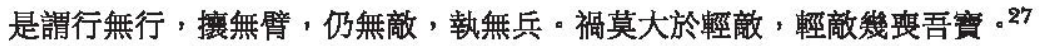

Arthur Waley (1889-1966) translated this as follows:

This latter is what we call to march without moving,

To roll the sleeve, but present no bare arm,

The hand that seems to hold, yet has no weapon in it.

A host that can confront, yet presents no battle-front.

Now the greatest of all calamities is to attack and find no enemy.

I can have no enemy only at the price of losing my treasure. ${ }^{28}$

Waley's interpretation happens to be a very good one to follow today. For the phrase qingdi 輕敵, "to take the enemy lightly," Waley, working in 1958, took a risk and followed the scantly attested variant unedi 無敵, "there is no enemy." In 1973, a few years after Waley's death, this reading was confirmed in both of the Mawangdui recensions. Despite his providential textual instincts, however, Waley's translation of the final line is somewhat opaque, ${ }^{29}$ and it is understandable that Le Guin wished to alter it. What she writes, however, is indefensible:

It's called marching without marching,

rolling up your sleeves without flexing your muscles,

being armed without weapons,

giving the attacker no opponent.

Nothing's worse than attacking what yields.

To attack what yields is to throw away the prize. ${ }^{30}$

"To throw away the prize" is loose, but creative, for sang une bao 征吾 璸. “To attack what yields," in contrast, is simply wrong. The original says: "There is no greater calamity than not to have an enemy"-or, in the socalled putative construction, "There is no greater calamity than thinking that one has no enemy." Yielding is a characteristic theme of the Daode jing, so Le Guin may have felt safe to insert it here. But that is a mistake. As long as she stays close to Waley, Le Guin is on firm ground; once she leaves him and sets out on her own, she stumbles. 
This raises point 2: All of these pseudotranslations are inaccurate. Their handling of chapter 10 , which contains some valuable references to meditation and other macrobiotic techniques, is telling:

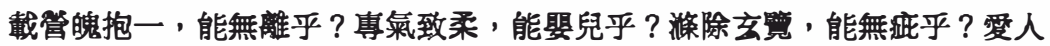 治國, 能無知乎? 天門開闧, 能為雌乎? 明白四達, 能無為乎 ? 31}

This is Chan's translation: ${ }^{32}$

Can you keep the spirit and embrace the One without departing from them? Can you concentrate your vital force and achieve the highest degree of weakness like an infant?

Can you clean and purify your profound insight so it will be spotless?

Can you love the people and govern the state without knowledge?

Can you play the role of the female in the opening and closing of the gates of Heaven?

Can you understand all and penetrate all without taking any action ?33 $^{33}$

Not one of the translations considered here manages to render these lines without tripping. Miles does best; his only errors occur in the first sentence: "While enabling your body and soul to embrace oneness-are you able to do it without needing to be secluded?"34 "While enabling your body and soul to embrace oneness" is impossible for zai ying po bao $y i$ 載營魄抱一, since there is no word in the original that could be construed as "to enable." We are asked to embrace oneness ourselves, not to enable our bodies and souls to do so. "Without needing to be secluded" is also questionable for neng une $l i$ 能無離. Literally that phrase means "can you be without parting?"; Chan interprets it as "without departing from them," and it might also mean "can you cause them not to part from you?" Miles' image of seclusion is distracting and imprecise. Le Guin also misses the sense of neng whe li: "Can you keep your soul in its body, hold fast to the one, and so learn to be whole?"35 "And so learn to be whole" may follow plausibly from "hold fast to the one," but it simplifies the original (and groundlessly inserts the notion of learning). Her rendition of the third sentence is tenuous, if vivid: "Can you keep the deep water still and clear, so it reflects without blurring?" Presumably, "deep water" is supposed to translate xuanlan 玄覽, the difficult compound that Chan renders as "profound insight." But lan can hardly mean "water."

Mitchell's translation is substantially freer: 
Can you coax your mind from its wandering

and keep to the original oneness?

Can you let your body become

supple as a newborn child's?

Can you cleanse your inner vision

until you see nothing but the light?

Can you love people and lead them

without imposing your will?

Can you deal with the most vital matters

by letting events take their course?

Can you step back from your own mind

and thus understand all things?

Where Miles and Le Guin struggle with neng une li, Mitchell simply ignores the phrase. Then he proceeds to rob the passage of its most dis tinctive image-playing the part of the female in the opening and closing of the gates of Heaven-replacing it with the New Age cliché "letting events take their course." In the final line, Mitchell employs another vapid locution, "step back from your own mind," and defuses all the tension in the original between understanding and not acting.

Bynner's translation is one of a kind:

Can you hold the door of your tent

Wide to the firmament?

Can you, with the simple stature

Of a child, breathing nature,

Become, notwithstanding,

A man?

Can you continue befriending

With no prejudice, no ban?

Can you, mating with heaven,

Serve as the fernale part?

Can your learned head take leaven

From the wisdom of your heart? ? $^{36}$

This is a species of poetry all its own, so distantly removed from the Chinese text that it would be senseless to point out all the "errors." The translations by Mitchell and Bynner take such liberties that they might be considered original works in their own right. The most relevant criterion, in that case, is not how faithfully Mitchell or Bynner reproduces the sense 
of the Chinese, but how the character of their work, taken as a whole, compares to that of the Daode jing. ${ }^{37}$

Third, the pseudotranslations distort and simplify the philosophy of the Daode jing. This is the gravest defect of all.

The late A. C. Graham published an incisive review of Bynner's translation in 1991, and his specific points need not be rehearsed here. ${ }^{38}$ Graham's general criticism is that Bynner systematically disburdens the original of its complexity. A typical example is found in the first couplet of chapter 5:

天地不仁, 以萬物為繁狗; 聖人不仁, 以百姓為別狗。39

These lines are straightforward: "Heaven and Earth are inhumane; they treat the Myriad Things as straw dogs. The Sage is inhumane; he treats the Hundred Clans as straw dogs." Here is Bynner's version:

Nature, immune as to the sacrifice of straw dogs,

Faces the decay of its fruits.

A sound man, immune as to the sacrifice of straw dogs,

Faces the passing of human generations. ${ }^{40}$

As Graham notes, this is not so much incorrect as overdetermined. The "straw dogs" 制狗 are accouterments at a sacrifice; thus they are accorded a crucial function at a certain time and place but are summarily discarded thereafter. The Sage, like Heaven and Earth, treats all things as straw dogs: he recognizes their momentary value but does not cling to them after their time has passed. ${ }^{41}$ To quote Graham:

The difference here is that Bynner, accustomed to mean only one thing at a time, cannot bear to risk being misunderstood, while Lao-tzu never apologises and never explains. The "Straw dogs" passage is naked vision defined with perfect economy... ; Lao-tzu does not qualify it, he leaves you to go in your own direction when you notice its collisions and interactions with other parts of the book. Bynner on the other hand is anxious to make it quite plain that Lao-tzu is recommending indifference, not to the welfare of other people, but to our common mortality. It is as though a translator of Blake's "Sooner murder an infant in its cradle than nurse unacted desires" were to adapt his phrasing to avoid the impression that he condones infanticide. $^{42}$ 
Graham might have pursued the matter even further, for the Daode jing may very well have recommended indifference to the welfare of other people after all. The statement that "Heaven and Earth are inhumane" was as mordant in the fourth century B.c. as it is today. Ancient readers would have been well acquainted with nature's capacity for cruelty. If we aspiring sages are to model ourselves after the Way of nature, then we too must be prepared to be inhumane when circumstances warrant. In Chinese, the implications of this little couplet are ferocious. Bynner, in trying to clarify them, makes them comfortable, if not banal.

Similar complaints were registered soon after the publication of Mitchell's book in 1988. From a philosophical point of view, the most serious problem is that Mitchell "has completely eliminated te from the text." 43 Mitchell's unease with the de in Daode jing is apparent on the very first page: "Tao Te Ching (pronounced, more or less, Dow Deh Jing) can be translated as The Book of the Immanence of the Way or The Book of the Way and How It Manifests Itself in the World or, simply, The Book of the Way."44

The Book of the Way would be Dao jing, not Daode jing. To be sure, elucidating de is not easy; it is one of the most difficult concepts in the text. ${ }^{45}$ But that is precisely why a modern translator must make a sustained effort to come to grips with it. Mitchell declines this task and rewrites the text so as to eliminate the problem. Wherever the original contrasts dao and de, Mitchell removes the more difficult term. Consider chapter 51:

\section{故道生之，德畜之、長之、育之、亭之、毒之、善之、覆之。46}

Wing-tsit Chan translates this as follows:

Therefore the Tao produces them and virtue fosters them.

They rear them and develop them.

They give them security and give them peace.

They nurture them and protect them. ${ }^{47}$

As the referent of "them" $之$ is left entirely unspecified, commentators have proposed dozens of different interpretations. What is critical, however one chooses to construe the sentence, is to recognize that dao and de are separate entities. Mitchell does not:

The Tao gives birth to all beings, nourishes them, maintains them, 
cares for them, comforts them, protects them, takes them back to itself.

Where the original has two protean subjects, Mitchell allows only one. A reader of the original has more to ponder.

Mitchell does not hesitate to rewrite the text as he pleases (in his words: "I have also paraphrased, expanded, contracted, worked with the text, played with it, until it became embodied in a language that felt genuine to me"), ${ }^{48}$ and his changes always have the effect of making the text easier. Chapter 39 discusses "the One" - (another concept that Mitchell conflates with $d a 0$ ), the mysterious vital force that permeates all provinces of the cosmos:

昔之得一者: 天得一以清, 地得一以審, 神得一以露, 谷得一以盈, 萬物得 一以生, 侯王得一以為天下貞・其致之, 天無以清將恐裂, 地無以害將忈

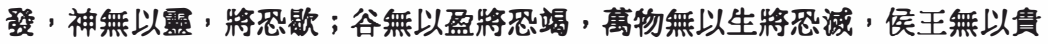
高，恐特踑。49

The translation of Chan:

Of old those that obtained the One:

Heaven obwined the One and became clear.

Earth obtained the One and became tranquil.

The spiritual beings obtained the One and became divine.

The valley obmined the One and became full.

The myriad things obtained the One and lived and grew.

King and barons obtained the One and became rulers of the empire.

What made them so is the One.

If heaven had not thus become clear,

It would soon crack.

If the earth had not thus become tranquil,

It would soon be shaken.

If the spiritual beings had not thus become divine,

They would soon wither away.

If the valley had not thus become full,

It would soon become exhausted.

If the myriad things had not thus lived and grown, They would soon become extinct.

If kings and barons had not thus become honorable and high in position, They would soon fall..$^{50}$ 
Mitchell then seizes upon Chan's word "extinct"51 and revises the entire passage accordingly:

In harmony with the Tao, the sky is clear and spacious, the earth is solid and full, all creatures flourish together, content with the way they are, endlessly repeating themselves, endlessly renewed.

When man interferes with the Tao, the sky becomes flthy, the earth becomes depleted, the equilibrium crumbles, creatures become extinct.

By turning this into a homily for environmentalism, ${ }^{52}$ Mitchell once again simplifies the original. The great cosmic axes of "Heaven and Earth" are reduced to "the sky" and "the earth," and all the other diverse elements of the universe, from "the spiritual beings" down to "the kings and barons," are compressed into the anodyne categories of "equilibrium" and "creatures." Where the Daode jing works on a canvas as large as the cosmos itself, Mitchell confines the text within a stereotyped postindustrial setting.

He also fails to conf ront the stark and troubling revelation that "kings and barons" are as essential to the mechanics of nature as Heaven and Earth themselves. This might have been an occasion to ask why the Daode jing seems to consider it natural for some men to rule others. Instead, Mitchell consistently mollifies the notoriously sinister political pronouncements in the text. ${ }^{53}$ Take the famous saying in chapter 3:

聖人治, 虛其心, 實其腹, 抲其志, 強其骨。54

The rule of the Sage: empty their minds, fill their bellies, weaken their wills, strengthen their bones.

Mitchell writes:

The Master leads

by emptying people's minds 
and filling their cores,

by weakening their ambition

and toughening their resolve.

"By emptying people's minds" is fine; the rest is benign and sentimental. The original is frightening. ${ }^{55}$

Even Le Guin, who is more concerned than Bynner and Mitchell about staying true to the original, occasionally prunes untidy passages that do not resonate with what she calls her "spiritual sense."56 Often these too involve politics, as in chapter 25:

有物混成, 先天地生寂漠！獨立不改, 周行不殆, 可以為天下母・吾不知其 名, 字之曰道, 吾強為之名日大, 大曰逝, 逝曰遠, 遠曰反。故道大, 天 大, 地大, 王亦大。域中有四大, 而王居其一焉 - 人法地, 地法天, 天法 道, 道法自然。57

Wing-tsit Chan's translation:

There was something undifferentiated and yet complete,

Which existed before heaven and earth.

Soundless and formless, it depends on nothing and does not change.

It operates everywhere and is free from danger.

It may be considered the mother of the universe.

I do not know its name; I call it Tao.

If forced to give it a name, I shall call it Great.

Now being great means functioning everywhere.

Functioning everywhere means far-reaching.

Being far-reaching means returning to the original point.

Therefore Tao is great.

Heaven is great.

Earth is great.

And the king is also great.

There are four great things in the universe, and the king is one of them.

Man models himself after Earth.

Earth models itself after Heaven.

Heaven models itself after Tao.

And Tao models itself after Nature. ${ }^{58}$ 
The prominent reference to the king, though in line with the depiction of the universe in chapter 39, appears to displease Le Guin. She truncates the chapter after the first section:

There is something

that contains everything.

Before heaven and earth

it is.

Oh, it is still, unbodied,

all on its own, unchanging,

all-pervading,

ever-moving.

So it can act as the mother

of all things.

Not knowing its real name,

we only call it the Way.

If it must be named,

let its name be Great.

Greatness means going on,

going on means going far,

and going far means turning back. ${ }^{59}$

In a supplementary note, Le Guin explains why she has deleted the final stanza: "I think a Confucian copyist slipped the king in. The king garbles the sense of the poem and goes against the spirit of the book. I dethroned him."60 Re-editing an ancient text by eliminating anything that clashes with one's chimeras about "the spirit of the book"-rather than enduring the agony of reconsidering one's assumptions-is anesthetized text criticism. Once again, the original Chinese discloses a vision that is vastly more difficult to comprehend than the translator's attenuated surrogate. ${ }^{61}$

Why do reputable presses continue to publish translations that borrow phrases uncritically from previous work, fail any basic test of accuracy, and diminish the philosophy of the original? One obvious answer is that they are profitable. Precise data concerning book sales are hard to come by, but the Internet bookseller Amazon.com indicates sales rankings 
for all its products and allows the public to share this information. The numbers, while probably unsuitable for a rigorous empirical study, paint a clear enough picture to be useful for my purpose. ${ }^{62}$

Three of the four works considered here have rankings in the top 100,000 . (To put this into perspective: Amazon sells over two million different titles.) The only exception is Miles' book, which was released by a tiny press and cannot be expected to compete (although its suggestive illustrations of women squatting in various bushy landscapes may indicate that Avery also hoped to market the title to a wide audience). Mitchell enjoys the highest ranking: 3,489, extraordinary for a work of literature. Here are, for the sake of comparison, the rankings of a few Western classics: The Selected Verse of Goethe (Penguin), 419,893; Aristotle, Nicomachean Ethics (Penguin), 195,613; Molière, The Miser and Other Plays (Penguin), 174,379; Dickens, Bleak House (Everyman), 55,116; Dante, The Divine Comedy (Everyman), 2,323. These figures leave little doubt that Mitchell's six-digit advance ${ }^{63}$ has long been earned back. Moreover, sales seem to be only increasing, and the many available translations have not come close to saturating the market. In 2001, Signet (an imprint of Penguin Putnam, Inc.) reissued the antique version by $R$. B. Blakney, undeterred by its obsolete introduction and discredited principles of translation; ${ }^{64}$ one year later, the book's ranking has already soared to 77,864 .

With so much money to be made, the central question is not why presses are publishing them but why people are buying them. Here too Amazon is helpful. The company posts ratings and reviews voluntarily submitted by registered customers, and although these voices represent only a minuscule fraction of Amazon's clientele, they are instructive. ${ }^{65}$ The respondents like the pseudotranslations, because, of the available choices, these are the most easily adaptable to their own experience. Scholarly translations seem pedantic to them: "As a poet, Bynner sees through the 'scholarly poo poo' of some translations and gives us what appears to be an effortlessly simple adaptation"; "Bynner avoids the lecture trap and captures the spirit of the original in a gentle way that speaks subtly to the reader and lingers in the heart." They explicitly prefer the simplicity of the pseudotranslations: "The bare, simple beauty of her language [seems] to me very much an expression of the Tao" (speaking of Le Guin); "There is nothing complicated, nothing intricate about Taoist wisdom.... I was very lucky to read her version, which has helped me see the beauty, the magic, the simplicity, the Tao"; "With non-sexist language and beautifully illustrating examples, [Mitchell] shows the modern westerner how to truly comprehend and embrace this wise and simple philos- 
ophy. Mitchell sometimes strays from the literal translation, but always for the better."

Above all, these reviewers applaud language that is readily understandable: "It is the duty of the translator to attempt to restate a classic for his or her generation, in a language that they can best understand"; "Le Guin's 'rendition' startled me with its everyday language and showed me the Tao in a new light." Just what is so desirable about "everyday language"? We do not go to the theater in order to hear Othello speak as though he were born in our generation. Americans make statements about the Daode jing that they would think twice before saying with regard to any other classic.

The Daodejing is old; it is alien; it is Chinese; and it is difficult. These are the recalcitrant facts that too many readers seem disinclined to accept. Instead, they seek out the most facile translations and consume insipid approximations of the original. This phenomenon must be attributable at least in part to intellectual laziness. The public is not obliged to restrict itself to academic monographs, but readers still have a responsibility to investigate the merit of a translation before adopting it. Not much research is necessary to discover that there is more to Daoism than "letting events take their course" and that the scary political overtones cannot be disregarded as the detritus of imaginary interpolators. Like any profound work of philosophy, the Daode jing is dangerous. We do it no justice by pretending that it is easy to swallow. Chinese philosophy made simple is no longer Chinese philosophy. 
